\title{
24
}

\section{Economic Interdependencies and Social Expenditures Revisited}

\section{Nils Düpont, Ivo Mossig, and Michael Lischka}

A short history of economic globalisation and welfare state development is indeed short with respect to several dimensions: economic globalisation in terms of trading goods is not a new phenomenon but has slowly increased over centuries; in contrast, foreign direct investments (FDI) as a driver of the third wave of globalisation gained momentum rather late and global production networks have only become much denser in recent years (Chap. 23). Compared to nearly a century of welfare state development, three decades of intense economic globalisation rather rapidly left a mark on social policies. Also, some countries "fall short" of economic globalisation as it is not equally distributed across the globe. It is highly concentrated at a core with massive flows and interdependencies between certain countries or groups of countries, while others at the periphery are hardly affected. Unsurprisingly, analyses of economic globalisation and welfare state development have not come up with distinct empirical evidence.

N. Düpont $(\bowtie) \bullet$ I. Mossig $\bullet$ M. Lischka University of Bremen, Bremen, Germany e-mail: duepont@uni-bremen.de; mossig@uni-bremen.de; lischka@uni-bremen.de 
Following a brief debate, it soon became clear that neither a globalist, nor sceptic or revisionist position prevailed (Genschel 2004). The former argued that internationalisation of the economy threatens the welfare state, undermining its viability (Cerny 1995). This position culminated in its probably best-known "race to the bottom" hypothesis. The sceptics questioned the impact of globalisation as many indicators of welfare state development did not show a downward trend-not to speak of convergence to the lowest common denominator aka a "neoliberal" model—nor did it restrict government's room for manoeuvre (Korpi and Palme 2003; Garrett 1998). Instead, welfare spending even increased to "compensate" or indemnify citizens for the risks of economic globalisation. The revisionist school, in turn, argued that economic globalisation helped "save" the welfare state from itself by triggering reforms and retrenchment of disproportionate demands and excessive financial liabilities (Rieger and Leibfried 2003). Focusing merely on the second phase of economic globalisation and on highly industrialised countries, the debate neither theoretically nor empirically led to conclusive results. In fact, economic globalisation does not have a short-term and direct impact on welfare states. It unfolds its impact through a chain of conditions, constraints and actions. Thus, states differ in their exposure, but foremost in their (political) response (Kwon and Pontusson 2010; Hays 2003). ${ }^{1}$ This is even more true for less developed political economies and their road to welfare (Haggard and Kaufman 2008; Segura-Ubiergo 2007).

Yet, hardly anyone would argue that economic globalisation has gone unnoticed. Especially since economic globalisation has further intensified and global crises showed how dense the international integration of markets has become. Building on Campbell's (2004) notion that globalisation rather has a subtle effect on institutional change, Busemeyer (2009) indeed finds evidence for the OECD countries that the globalists were probably right after all, with economic openness having a negative impact on social spending. But what is more: "The reason why most of the pertinent studies have not picked up on this effect is that they (...) focus

\footnotetext{
${ }^{1}$ For a discussion of an even longer causal chain of globalisation working via electoral demands and party competition, see, for example, Kayser (2007); Ezrow and Hellwig (2014).
} 
on a time period in which globalisation effects have not played out yet" (2009, 456).

In line with Busemeyer's notion, we extend Campbell's (2004, 167) question "What if we wait a little longer?" and add "What if we broaden our scope?" Reviewing the globalist perspective, we confront it with descriptive statistics for the third phase of globalisation, looking at FDIs and public social expenditure in seventy countries from 1995 to 2015 . Our tentative results suggest that different modes of integration into the global economy-depending on whether a country is a net recipient or sender of FDIs - trigger two processes: rich countries with a surplus of outward stocks and/or increasing engagement abroad compensate their citizens, resulting in increased social spending. At the same time, FDI inward stocks and/or increasing inflows help less developed countries to implement and fund social policies. This short history reminds us of the need to reassess the globalisation-welfare state nexus from time to time in line with Streeck's $(2007,544)$ notion that a "historical perspective must allow for the possibility that the present may be governed by different laws than the past".

\section{Changing Times}

The third phase of economic globalisation fundamentally differs from the second phase (Chap. 23). While the latter was characterised mainly by trade relations, the former was and still is shaped by the establishment of global production networks and a progressive integration of the financial sector and capital markets. According to the "economic logic of globalization" (Swank 2010, 320), choices made by companies-relentlessly and globally looking for the highest return rate on their investment- "force" governments to engage in a global competition for the lowest production costs, lowest labour costs, fewest regulations and lowest tax rates to "attract" capital investments and hold mobile assets. Resident, but exportoriented companies may also call for retrenchment to become more competitive on the global market. Accordingly, governments should cut back their welfare efforts and reduce any disincentives to work and invest. Yet, there neither was nor is clear-cut empirical evidence for a neoliberal "race 
to the bottom". While the "efficiency hypothesis" has been criticised for being too simplistic, it also neglects non-cost-based factors emphasised by location theorists that affect companies' locational choices, such as knowledge-based motives and access to human capital (Giese et al. 2011). Certain welfare policies like active labour market policies, training and education actually do play a role in "attracting" investments as well.

Leaving the critique of theoretical shortcomings aside, one cannot deny the fact that FDIs massively increased in the third phase-partly motivated by "production cost criteria" and rent seeking but also due to strategic merger and acquisition activities of transnational companiesand that governments have to (re)act. As such, FDI flows have often been used in macro-comparative studies to approximate the "integration" of a country into the global economy. But Scruggs $(2004,10)$ rightfully cast doubt on the simple use of FDIs: "Does a high level reflect that said government is accommodating to capital?" Likewise, would FDI outflows signal a country is not amenable to capital, despite its investment abroad? He proceeds: "Measures of FDI stocks (assets held by foreigners) might provide a better indicator of vulnerability to 'external' imperatives". Even then, one must consider that FDIs have a source and a destination and therefore may have countervailing effects that go unnoticed in pooled analyses estimating average effects across samples.

\section{$24+2$ Modes of Integration into the Global Economy}

Picking up Scruggs' suggestions, Fig. 24.1 plots the ratio of FDI inward to outward stocks for seventy countries from all continents for which data from the World Bank on FDIs and from the ILO on social expenditure is available. Covering countries with different levels of economic development, in 1995 (our starting year) fourteen countries had a GDP per capita $<1000$ US\$, thirty countries had a GDP per capita between 1000 and 10,000 US\$, and thirty-six countries had a GDP per capita $>10,000$ US\$. All in all, 4.3 billion people were living in these countries in 2015. The $x$-axis shows the ratio for 1995 and the $y$-axis for 2015 on a logarithmic scale to capture extreme observations (Turkey, e.g. had a ratio of 

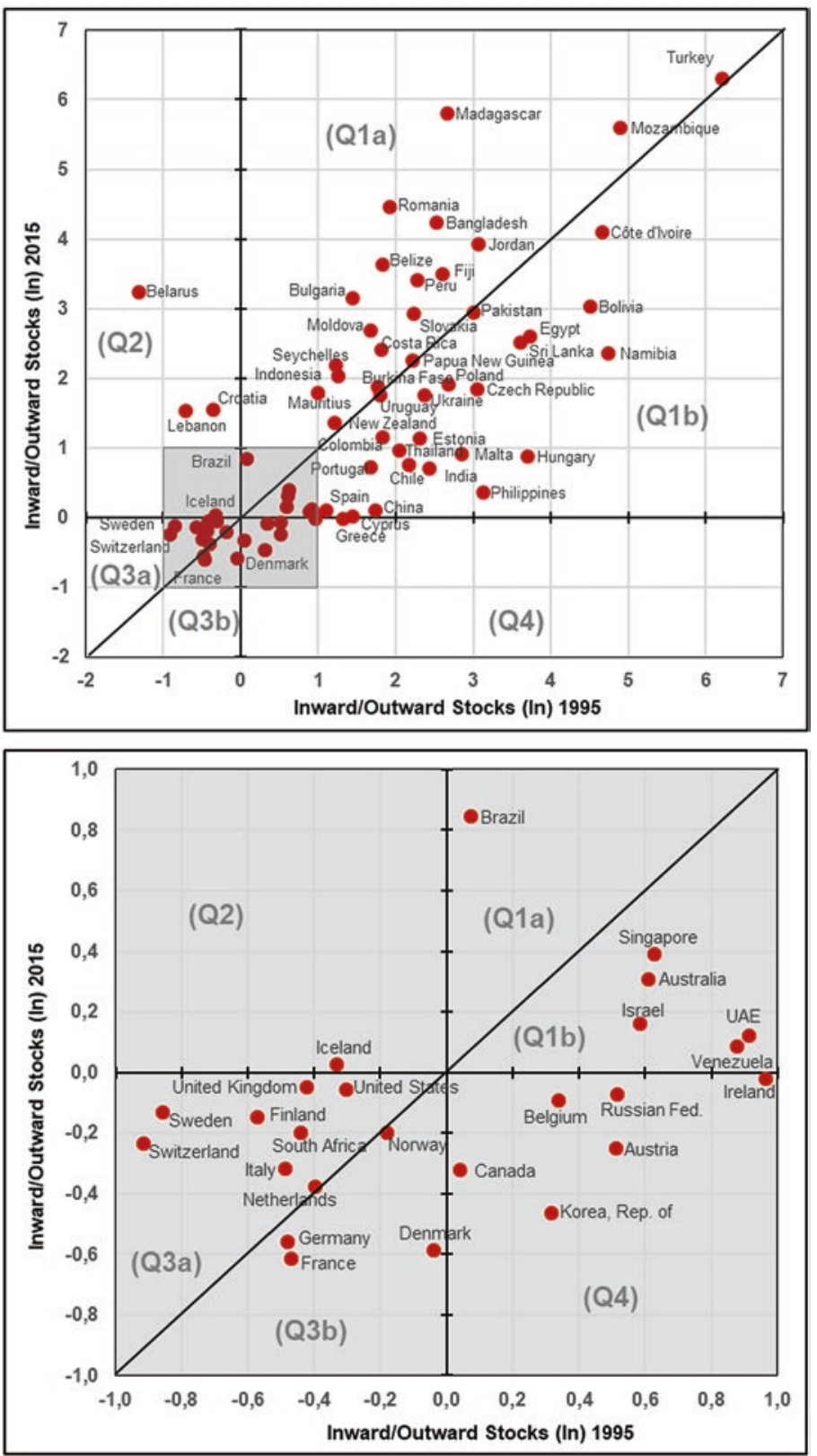

Fig. 24.1 Ratio of FDI inward/outward stocks 1995 and 2015. (Sources: World Bank https://data.worldbank.org; Accessed March 8, 2021; own calculations) 
546:1 in 2015). Positive values indicate target countries where equity held by foreign investors in enterprises resident in the focal country is higher than domestic investors' assets in foreign economies. The reverse is true for negative values reflecting source countries of FDIs. Figure 24.1a provides the "grand picture"; Fig. 24.1b zooms in on the range $(-1,1)$ for unpacking the countries clumped together at the centre.

The plotting reveals several notable developments over the last two decades: Only few countries are close to the diagonal line meaning their ratio of inward/outward stocks hardly changed. The bulk of countries, however, experienced shifts in their FDI stocks ratio. In general, countries above the diagonal line "attracted" more foreign capital compared to their foreign investments between 1995 and 2015, strengthening their position as preferred destinations for investments. Countries below the line increased their outward stocks from 1995 to 2015 in relation to inward stocks, reinforcing their position as source countries of FDIs. With the diagonal line splitting quadrants 1 and 3 , we can identify $4+2$ modes of integration into the global economy. Those countries, in principle, retained their ratio of inward/outward stocks but took different paths.

- Quadrant 1: more inward than outward FDI stocks, i.e. "attractor countries".

- Raising attractors (Q1a): While countries like Brazil, Romania, Bangladesh, Madagascar or Peru already had a surplus of inward stocks in 1995, this "imbalance" further intensified until 2015, meaning those countries rely even more on FDIs from abroad.

- Decreasing attractors (Q1b): Countries like Bolivia, Portugal, Czech Republic, Namibia, Egypt, China or India still lean on FDIs but their relevance vis-à-vis outward stocks decreased, meaning those countries became more engaged in countries elsewhere.

- Quadrant 3: more outward than inward FDI stocks, i.e. "investor countries".

- Decreasing investors (Q3a): While Q3 mostly hosts European countries, some, like Switzerland, Sweden, Finland, Italy, but also South Africa, UK and USA reduced their excess of outward FDIs. 
- Raising investors (Q3b): On the contrary, Germany, France, Norway and Denmark even increased their relative surplus of outward stocks from 1995 to 2015 .

Only few countries shifted their balance either from being a sender to becoming a destination (inverted attractors [Q2]: Belarus, Lebanon, Croatia and Iceland) or vice versa to becoming a source of FDIs (inverted investors [Q4]: Canada, South Korea, Colombia, Belgium, Austria, Russia, Ireland and Greece).

The plots corroborate Scruggs' notion as to why the effects of FDIs in empirical studies may cancel each other out. Depending on whether countries are net recipients or senders, FDIs pose different imperatives or incentives on governments, leading to diverging (social) policy responses. According to neo-classical economics, it is rich countries that can especially "afford" to invest in poorer countries as labour is cheaper there, capital scarce and, consequently, the return on investment higher. At the same time FDI inflows have been identified as strong drivers of GDP growth. Therefore, FDIs may have at least two effects: for less developed countries, a high(er) level of inward stocks helps growth. Following Wilensky (1975), this, in turn, affects the demand for social policies but also enables these countries to implement and fund social policies. In line with the "efficiency hypothesis", for rich countries, however, outward investments often go along with relocation of production sites, job losses and decreasing tax bases. This brings us back to the initial starting point of the globalisation debate: whether FDIs in developed countries have a negative effect on social spending due to "efficiency reasons" or rather trigger an increase to compensate those who "lose" from economic globalisation.

Taking a bird's eye perspective, we therefore look at the development of GDP and aggregate public spending on social protection. Table 24.1 reports descriptive summary statistics for the $4+2$ groups identified above. At first glance, social spending increased remarkably in all quadrants, both per capita and as a percentage of GDP. Even for the rich countries there is no fundamental dismantling of the welfare state or a "race to the bottom"-at least not in terms of spending. While being tentative, there are hints that we indeed witness two developments at the same time: 


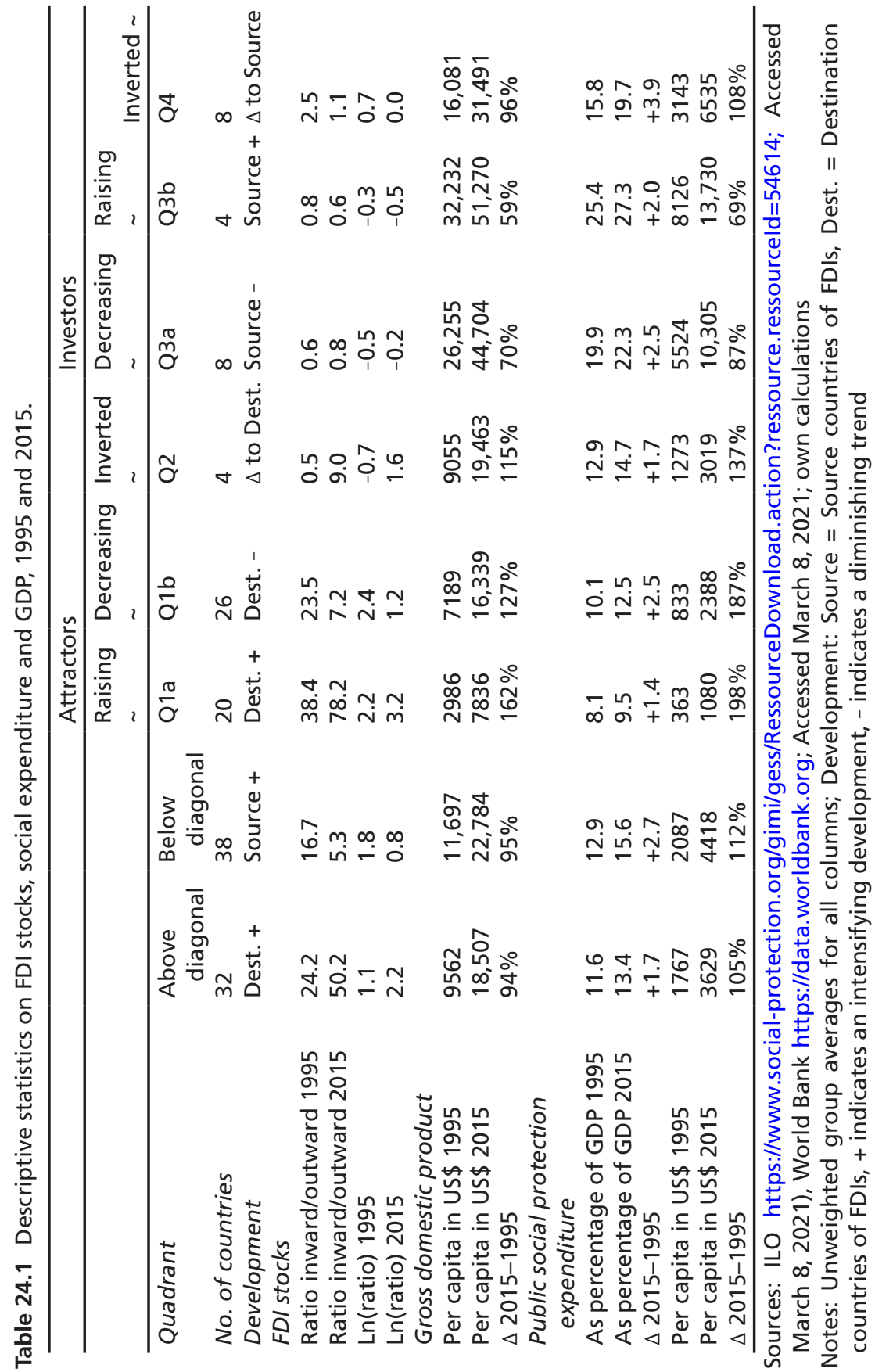


Countries below the diagonal line were already a source for FDIs in 1995 and/or increasingly engaged in investments abroad since then. Compared to countries above the line that already were and/or increasingly became a destination, GDP developed almost on par. Yet, spending as a percentage of GDP and per capita markedly increased for the richer, sending countries. Thus, a surplus of outward stocks goes hand in hand with increased spending, lending support to the "compensation hypothesis".

More importantly though, FDI inflows positively affect GDP with the highest growth rates observable for countries in Q1a. They already relied on inward stocks in 1995 and have "attracted" even more inflows since then. Still leaning on inward stocks as well but becoming more engaged abroad, countries in Q1b show an above-average GDP growth, but less so than Q1a. Likewise, countries that shifted their balance and became a destination (Q2) more than doubled their GDP. While social spending as a percentage of GDP only slightly increased, there is a notable peculiarity: Countries in Q1 and Q2 started from a very low level but massively increased their social spending per capita. Supporting Wilensky's notion, with increasing development these states not only have a higher need to provide but can also afford more social policies. Furthermore, spending "laggards" catch up; whether this leads to a convergence of economic, political and social structures, as Wilensky (1975) also suggests, remains to be seen.

Looking at the richer source countries there is further support for the "compensation hypothesis": Countries in Q3b actually spend more on social protection both as a percentage of GDP and per capita than those in Q3a. The former are countries with a large surplus in 1995 that even increased their outward stocks. Finally, few countries that switched from destination to source show the highest increase in social spending, again supporting the idea that states need to indemnify citizens for the risks of economic globalisation.

These figures suggest that there are two processes underway related to FDIs: First, either relying on or increasing FDI outward stocks seems to entail compensatory measures. At the same time, we witness a timeshifted modernisation of less developed countries triggered by inflows and inward stocks. 


\section{The Road Ahead}

As Genschel $(2004,626)$ noted, "it appears most likely that a globalizationinduced increase in the permeability of national borders will give rise simultaneously to more tax competition and greater demands for social compensation for external economic risks". This is still true when looking at the third phase of economic globalisation that is less shaped by trade relations, but rather by the establishment of global production networks and capital market integration. Inspecting the ratio of inward to outward FDI stocks, it becomes clear that FDIs do not and cannot have a uniform impact on welfare efforts. As Scruggs (2004) rightfully argued, one needs to consider FDIs more carefully. Our descriptive account shows that it will make a difference whether a country is a net recipient or sender, whether it increases its imbalance, matches its ratio or even shifts its stocks. In addition, one cannot deny the (increasing) importance of FDIs but the "Lucas paradox" also calls the neo-classical assumption into question that capital flows from rich countries to poorer ones. Instead, institutions matter for attracting and holding mobile capital from rich countries (Alfaro et al. 2008).

While our short history rather lends support for the "compensation hypothesis" (again), it also shows that we may witness a renaissance of functional and institutional explanations with a time-shifted evolution of less developed countries and their road to welfare-fuelled by inward FDIs. For this reason, we agree with Busemeyer, Campbell and Streeck: sometimes, we just need to wait, revisit and re-specify our hypotheses allowing for the possibility that the past is governed by different laws than the present.

Acknowledgements This chapter is a product of the research conducted in the Collaborative Research Center "Global Dynamics of Social Policy" at the University of Bremen. The centre is funded by the Deutsche Forschungsgemeinschaft (DFG, German Research Foundation)—project number 374666841-SFB 1342. 


\section{References}

Alfaro, Laura, Sebnem Kalemli-Ozcan, and Vadym Volosovych. 2008. Why Doesn't Capital Flow from Rich to Poor Countries? An Empirical Investigation. The Review of Economics and Statistics 90 (2): 347-368.

Busemeyer, Marius R. 2009. From Myth to Reality: Globalisation and Public Spending in OECD Countries Revisited. European Journal of Political Research 48 (4): 455-482.

Campbell, John L. 2004. Institutional Change and Globalization. Princeton: Princeton University Press.

Cerny, Philip G. 1995. Globalization and the Changing Logic of Collective Action. International Organization 49 (4): 595-625.

Ezrow, Lawrence, and Timothy Hellwig. 2014. Responding to Voters or Responding to Markets? Political Parties and Public Opinion in an Era of Globalization. International Studies Quarterly 58 (4): 816-827.

Garrett, Geoffrey. 1998. Partisan Politics in the Global Economy, Cambridge Studies in Comparative Politics. Cambridge: Cambridge University Press.

Genschel, Philipp. 2004. Globalization and the Welfare State: A Retrospective. Journal of European Public Policy 11 (4): 613-636.

Giese, Ernst, Ivo Mossig, and Heike Schröder. 2011. Globalisierung der Wirtschaft: Eine wirtschaftsgeographische Einführung. Paderborn: Schöningh.

Haggard, Stephan, and Robert R. Kaufman. 2008. Development, Democracy and Welfare States: Latin America, East Asia, and Eastern Europe. Princeton: Princeton University Press.

Hays, Jude C. 2003. Globalization and Capital Taxation in Consensus and Majoritarian Democracies. World Politics 56 (1): 79-113.

Kayser, Mark A. 2007. How Domestic Is Domestic Politics? Globalization and Elections. Annual Review of Political Science 10: 341-362.

Korpi, Walter, and Joakim Palme. 2003. New Politics and Class Politics in the Context of Austerity and Globalization: Welfare State Regress in 18 Countries, 1975-95. American Political Science Review 97 (3): 425-446.

Kwon, Hyeok Y., and Jonas Pontusson. 2010. Globalization, Labour Power and Partisan Politics Revisited. Socio-Economic Review 8 (2): 251-281.

Rieger, Elmar, and Stephan Leibfried. 2003. Limits to Globalization: Welfare States and the World Economy. Cambridge: Polity Press.

Scruggs, Lyle. 2004. Research on Globalization and the Welfare State: Do We Know What We Think We Know? Paper Prepared for the Duke University Summer Institute on Globalization and Equity, Durham. 
Segura-Ubiergo, Alex. 2007. The Political Economy of the Welfare State in Latin America: Globalization, Democracy, and Development. Cambridge: Cambridge University Press.

Streeck, Wolfgang. 2007. 'Globalization': Nothing New Under the Sun? SocioEconomic Review 5 (3): 537-547.

Swank, Duane H. 2010. Globalization. In The Oxford Handbook of the Welfare State, ed. Francis G. Castles, Stephan Leibfried, Jane Lewis, Herbert Obinger, and Christopher Pierson, 318-330. Oxford: Oxford University Press.

Wilensky, Harold L. 1975. The Welfare State and Equality: Structural and Ideological Roots of Public Expenditures. Berkeley: University of California Press.

Open Access This chapter is licensed under the terms of the Creative Commons Attribution 4.0 International License (http://creativecommons.org/licenses/ by/4.0/), which permits use, sharing, adaptation, distribution and reproduction in any medium or format, as long as you give appropriate credit to the original author(s) and the source, provide a link to the Creative Commons licence and indicate if changes were made.

The images or other third party material in this chapter are included in the chapter's Creative Commons licence, unless indicated otherwise in a credit line to the material. If material is not included in the chapter's Creative Commons licence and your intended use is not permitted by statutory regulation or exceeds the permitted use, you will need to obtain permission directly from the copyright holder.

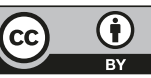

